\title{
Implementasi Undang-Undang Nomor 7 Tahun 2017 Tentang Pemilihan Umum Di Kota Makassar: Studi Bawaslu Provinsi Sulawesi Selatan
}

\author{
Aslang Jaya, Darussalam Syamsuddin, Alimuddin \\ Program Studi Hukum Tatanegara UIN Alauddin Makassar
}

\begin{abstract}
Abstrak
Studi ini membahas tentang sejauhmana peran Bawaslu Provinsi SulawesiSelatan dalam menerapkan Undang-Undang Nomor 7 Tahun 2017 tentang Pemilihan Umum untuk meminimalisir pelanggaran Pemilu di Kota Makassar. Jenis Penelitian ini ialah penelitian deskriptif kualitatif lapangan. Penelitian ini dilakukan untuk mengumpulkan sejumlah data yang diperoleh dari informan di lapangan untuk menemukan berbagai fakta atau fenomena sosial, kemudian menganalisisnya dan berupaya melakukan teorisasi berdasarkan apa yang diamati. Lokasi Penelitian dilakukan di Kota Makassar. Lokasi ini dipilih karena memiliki semua aspek pendukung agar dapat berjalan dengan baik dan Kota Makassar terkenal sebagai daerah sentral politik di Sulawesi Selatan.
\end{abstract}

Kata Kunci :

Implementasi, Undang-Undang Pemilu, Pelanggaran Pemilu, Bawaslu

\section{PENDAHULUAN}

Studi ini membahas tentang sejauh mana peran Bawaslu Provinsi Sulawesi-Selatan dalam menerapkan Undang-Undang Nomor 7 Tahun 2017 tentang Pemilihan Umum untuk meminimalisir pelanggaran Pemilu di Kota Makassar.

Secara garis besar Pemilihan Umum merupakan suatu solusi terhadap persoalan demokrasi modern dan juga merupakan upaya memecahkan masalah keterwakilan yaitu bagaimana mewakili berbagai kelompok, kekuatan politik, kepentingan maupun rakyat secara keseluruhan.
Didalam suatu Negara demokratik seperti Indonesia, demokrasi perwakilan dijadikan bagian integral untuk mewujudkan kesejahteraan masyarakat melalui wakilnya di kekuasaan legislatif maupun pemimpinannya di eksekutif agar kepentingan masyarakat tersebut dapat terejewantah dalam kehidupan nyata. ${ }^{1}$

Pada umumnya, bangsa Indonesia menginginkan perwujudan Pemilu yang berkualitas yakni suatu Pemilu yang

\footnotetext{
${ }^{1}$ Agus Pramono, Elite Politik: Yang Loyo dan Harapan Masa Depan (Jakarta: Pustaka Sinar Harapan, 2005), h. 11.
} 
berlangsung secara demokratis serta dapat menghasilkan wakil-wakil rakyat dan pemimpin negara yang negarawan. Pendambaan terhadap wakil rakyat dan pemimpin itu, masyarakat menginginkan agar mereka mampu menghadirkan kesejahteraan di berbagai lini kehidupan serta mampu mengangkat harkat dan martabat bangsa di mata intrernasional. ${ }^{2}$ Karena masyarakat tidak menginginkan pemimpin atau wakilnya yang telah duduk di Parlemen lebih mementingkan kepentingan kelompok maupun golongannya dibanding kepentingan rakyatnya sendiri secara kolektif. Karena tujuan Pemilu ialah menghasilkan pemimpin atau wakil rakyat yang mampu menghadirkan solusi terhadap suatu masalah dalam kehidupan bermasyarakat agar mampu mewujudkan kesejahteraan dan keadilan di segala lini kehidupan berbangsa dan bernegara.

Kendati demikian, pernah muncul satu akronim ditengah masyarakat yang menilai bahwa Pemilu merupakan singkatan dari 'pembuat pilu' yakni satu hal yang menyebabkan hati menjadi pilu. Padahal, pemilu diperuntukkan untuk mengaplikasikan demokrasi di Indonesia, karena adagium klasik pernah mengemukakan bahwa "tidak ada demokrasi tanpa Pemilu". Yang menjadi soal ialah, mengapa akronim yang muncul ditengah masyarakat dan masih eksis menjadi pembicaraan publik masih terjadi? Hal itu merupakan satu gambaran

${ }^{2}$ Rozali Abdullah, Mewujudkan Pemilu yang Lebih Berkualitas (Pemilu Legislatif) (Jakarta: Rajawali Pers, 2009), h. 3. bahwa dalam praktiknya Pemilu yang diselenggarakan itu kerapkali memuncul kan tragedi yang memilukan, terutama sejak masa Orde Baru. Karena saat itu, Pemilu yang diselenggarakan oleh Negara, menjadi hal yang menakutkan bagi masyakarat karena Negara melakukan kekerasan politik terhadap warga negaranya dengan cara mengintruksikan rakyat agar mendukung pemerintah dan partai politik tertentu. ${ }^{3}$

Hal tersebut bukanlah suatu hal yang lumrah dalam Negara demokratis seperti Indonesia, akronim maupun adagium yang muncul dalam masyarakat tentunya diakibatkan oleh kurangnya professionalitas elti politik dalam mengelola pemerintahan. Secara historis, dalam sejarah kemerdekaan, bangsa Indonesia kerapkali mengalami krisis dikarenakan para elite politik senantiasa mempertontonkan sikap primordial kepada masyarakat. Hal itu terjadi karena para aktor politik tidak konsekuen dengan komitmen yang telah dibangun oleh founding father's bangsa. Akibatnya sengkarut kenegaraan muncul dengan eksis, contohnya ialah timbulnya budaya feodalistik. ${ }^{4}$

Indonesia yang menganut sistem demokrasi modern dan warga Negara yang mengharapkan penyelenggaraan Pemilu bukan hanya sekedar ritual suksesi

\footnotetext{
${ }^{3}$ Moh. Mahfud MD, "Kata Pengantar", dalam Ni'matul Huda \& M. Imam Nasef, Penataan Demokrasi dan Pemilu di Indonesia Pasca Reformasi (Jakarta: Kencana, 2017), h. viii.

${ }^{4}$ Agus Pramono, h.52.
} 
kepemimpinan semata, melainkan lebih dari itu. Pemilu diharapkan mampu mewujudkan kedaulatan rakyat. Salah satu elemen terpenting dalam Negara demokratis seperti Indonesia yang menerapkan pemilu ialah eksisnya lembaga penyelenggara Pemilu yang memiliki payung hukum dan tegas diatur oleh aturan Negara. Tugas dan fungsi lembaga penyelenggara Pemilu ini ialah mengatur jalannya pemilu. Berhasil atau tidaknya penyelenggaran Pemilu sebagaimana tujuannya, tergantung dari pihak penyelenggara. Maka dari itu, pihak penyelenggara inilah yang memiliki peran sangat pentng dalam penyelenggaran pemilu di Indonesia. ${ }^{5}$

Seperti diketahui, lembaga penyelenggara Pemilu di Indonesia dalam hal ini Komisi Pemilihan Umum (KPU). KPU merupakan institusi Negara yang diberikan wewenang menyelenggarakan Pemilu yang bebas dari pengaruh apapun serta bersifat tetap dan mandiri. Sedangkan penyelenggaraan Pemilu secara jelas teratur dalam Undangundang Nomor 7 Tahun 2017 tentang Pemilihan Umum. Peran KPU disini ialah menjalankan pemilu sesuai koridor hukum yang berlaku dalam Undang-Undang Pemilu.

Selain KPU sebagai institusi yang diberikan kewenangan dalam penyelenggaraan pemilu, adapun lembaga lain yang saling berkoordinasi dengan KPU dalam menyelenggarakan pemilu.

\footnotetext{
${ }^{5}$ Ni'matul Huda \& M. Imam Nasef, Penataan Demokrasi dan Pemilu di Indonesia Pasca Reformasi (Jakarta: Kencana, 2017), h. 52.
}

Lembaga tersebut ialah Badan Pengawas Pemilu (Bawaslu) yang diberikan kewenangan mengawasi tahapan penyelenggaraan pemilu, yang meliputi pemilu anggota DPR, DPD, DPRD, Pemilu Presiden dan Wakil Presiden, serta Pemilu Kepala Daerah dan Wakil Kepala Daerah. Lembaga Bawaslu diwajibkan menjalankan profesionalitas kerja dalam penyelenggaraan Pemilu, adapun beberapa kewajiban yang diamanatkan oleh Negara terhadap lembaga ini diantaranya: bersikap tidak diskrimininatif dalam menjalankan tugas dan wewenanganya; menerima menindaklanjuti laporan yang berkaitan dengan dugaan pelanggaran pemilu; dan beberapa tugas yang terakomodir secara tegas dalam Undang-Undang Pemilu. ${ }^{6}$

Dalam setiap agenda penyelenggaraan Pemilu, banyak terjadi berbagai jenis pelanggaran dalam penyelenggaraannya, seperti Pemilu yang diselenggarakan tahun 2019. Seperti data dari Bawaslu yang mencatat ada sebanyak 7.000 kasus yang diduga merupakan pelanggaran pemilu. Diantara kasus dan laporan tersebut, pihak Bawaslu mengungkapkan bahwa ada sebanyak 548 temuan yang masuk dalam kategori pelanggaran pidana pemilu dan sisanya merupakan pelanggaran administrasi, kode etik maupun pelanggaran hukum yang lain. ${ }^{7}$

\footnotetext{
${ }^{6}$ Rozali Abdullah, h. 103.

${ }^{7}$ Mela Arnani, "Bawaslu Temukan 548 Pelanggaran Pidana Pemilu, Ini Paparannya" dalam https://nasional.kompas.com/read/2019/04/09/1819 0341/bawaslu-temukan-548-pelanggaran-pidana pemilu-ini-paparannya, diakses pada 5 Mei 2019.
} 
Hal yang kerapkali terjadi yang masuk dalam kategori pelanggaran Pemilu ialah maraknya praktik politik uang (money politic) yang banyak ditemukan terutama di tingkat elektoral. Hal tersebut merupakan rahasia umum dalam tiap penyelenggaraan Pemilu. Seperti di Kota Makassar misalnya, Bawaslu Kota Makassar menemukan banyak laporan dari masyarakat tentang pelanggaran pemilu, dan dari temuan tersebut, yang paling banyak ditemukan ialah praktik politik uang. ${ }^{8}$

Berbagai fenomena yang terjadi terkait pelanggaran Pemilu ketika pesta demokrasi lima tahunan diselenggarakan merupakan hal yang harus dihindari atau dilawan, karena persoalannya ialah jika hal tersebut tetap berlangsung maka akan merusak sendi-sendi kehidupan demokrasi di Indonesia. Negara telah mengatur warga negaranya dengan cara membentuk berbagai regulasi agar ketertiban dan kenyamanan dalam bernegara atau menjadi warga negara dapat teraktualisasi dalam kehidupan berbangsa.

Berdasarkan latar belakang yang telah dikemukakan di atas, maka peneliti berinisiatif untuk menjawab pertanyaan mengenai sejauhmana peran Bawaslu Provinsi Sulawesi-Selatan dalam menerapkan Undang-Undang Nomor 7 Tahun 2017 tentang Pemilihan Umum

\footnotetext{
${ }^{8}$ Himawan, "Bawaslu Banyak Temukan Dugaan Politik Uang Pada Pelanggaran Pemilu di Makassar" dalam https://regional.kompas.com/read /2019/04/13/13044661/bawaslu-banyak-temukandugaan-politik-uang-pada-pelanggaran-pemilu-di, diakses pada 5 Mei 2019.
}

untuk meminimalisir pelanggaran Pemilu di Kota Makassar.

\section{KAJIAN PUSTAKA}

Sebelum menjelaskan lebih jauh mengenai sejauh mana peran Bawaslu Provinsi Sulawesi-Selatan dalam menerapkan Undang-Undang Nomor 7 Tahun 2017 tentang Pemilihan Umum untuk meminimalisir pelanggaran Pemilu di Kota Makassar. Berikut ini beberapa studi pustaka yang dapat membantu memetakan hal-hal apa saja yang telah dan belum dijelskan oleh penelitian terdahulu.

Rozali Abdullah dalam bukunya "Mewujudkan Pemilu yang Lebih Berkualitas (Pemilu Legislatif)" mengatakan bahwa pemilu yang berkualitas pada dasarnya dapat dilihat dari dua sisi, yakni sisi proses dan hasilnya. Pemilu dapat dikatakan berkualitas dari sisi prosesnya apabila pemilu itu berlangsung secara demokratis, aman, tertib,dan lancar serta jujur dan adil. Sedangkan dilihat dari sisi hasilnya, pemilu itu harus mampu menghasilkan pemimpin ataupun wakil-wakil rakyat yang mampu mengamalkan amanat konstitusi negara.

Dalam bukunya tersebut, penulis lebih mengarah pada persoalan mekanisme penyelenggaran pemilu yang baik dan benar dengan berpatokan pada penyelengggaran pemilu tahun 2004, dalam buku ini belum secara gamblang menjelaskan mengenai implementasi UU 
Pemilu dalam meminimalisir terjadinya pelanggaran Pemilu di Sulawesi-Selatan.

A. Bakir Ihsan dalam bukunya "Etika dan Logika Berpolitik" mengatakan bahwa etika politik merupakan suatu muara sintesis dari logika yang berkembang pada ranah publik demi terbangunnya kohesi sosial. Pelanggaran terhadap etika politik merupakan suatu tanda bahwa matinya nalar kebangsaan warga negara yang dapat mengancam integrasi sosial. Buku ini merupakan wacana kritis terhadap perilaku elit politik yang tidak mencerminkan politik etis sebagai seorang politisi sekaligus warga negara. Karena kerapkali ditemukan, kebanyakan elit politik lebih condong mengutamakan kepentingan kelompok atau golongannya dibanding kepentingan warga negara. ${ }^{9}$ Di dalam buku hanya menarasikan persoalan kemelut kepentingan yang dimainkan oleh para aktor politik, kendati tidak menjelaskan sejauh mana implementasi UU Pemilu dalam meminimalisir terjadinya pelanggaran Pemilu.

Hafied Cangara dalam bukunya "Komunikasi Politik: Konsep, Teori, dan Strategi" mengemukakan bahwa sejak era pasa reformasi seperti sekarang ini, kondisi perpolitikan di Indonesia jauh lebih dinamis dikarenakan terbukanya ruang-ruang dialektis dan negara lebih

${ }^{9}$ A. Bakir Ihsan, Etika dan Logika Berpolitik (Bandung: Remaja Rosdakarya, 2009). menghargai hak-hak individu dalam setiap pembuatan kebijakannya. ${ }^{10}$

Metodologi baru dalam pentas demokrasi seperti pemilihan langsung yang dilakukan masyarakat terhadap para calon wakilnya di parlemen maupun pemimpinnya disegala strata pemerintahan merupakan wajah baru dalam kondisi demokrasi sekarang ini. Tidak hanya itu, para elit politik dalam mengkampanyekan dirinya sebagai bagian dari peserta pemilu telah disediakan ruang untuk mereka atau disediakan berbagai medium, seperti televisi, radio, surat kabar,maupun kampanye di media sosial. Sebagai pembanding, dalam buku ini belum menjelaskan mengenai salah satu produk reformasi seperti UU Pemilu yang diorientasikan sebagai landasan warga negara dalam penyelenggaraan Pemilu agar tidak terjadi kembali pelanggaranpelanggaran Pemilu seperti sebelumnya, dan juga belum memaparkan tugas dan fungsi Badan Pengawas Pemilu yang dibentuk oleh negara untuk mengawasi jalannya Pemilihan Umum di tiap penyelenggaraannya.

Dari kajian literatur di atas, yang menjadi pembeda antara penelitian ini dengan ketiga penelitian sebelumnya ialah tidak dijelaskannya mengenai sejauhmana peran Bawaslu Provinsi Sulawesi-Selatan dalam menerapkan Undang-Undang Nomor 7 Tahun 2017 tentang Pemilihan Umum

\footnotetext{
${ }^{10}$ Hafied Cangara, Komunikasi Politik:
} Konsep, Teori, dan Strategi (Jakarta: Rajawali Pers: 2009). 
untuk meminimalisir pelanggaran Pemilu di Kota Makassar.

\section{PEMILU SEBAGAI HAKIKAT DEMOKRASI}

Pemilu sebagai sarana bagi masyarakat untuk ikut berpartisipasi dalam memberikan suaranya guna memilih wakil rakyat, serta merupakan bukti adanya upaya untuk mewujudkan demokrasi. Secara operasional pemilihan umum diartikan sebagai suatu lembaga sekaligus praktik politik yang memungkinkan untuk terbentuknya suatu pemerintahan perwakilan (representative goverment). Pemilu juga disebut dengan arena political market yang berarti bahwa Pemilu menjadi tempat dan individu atau masyarakat untuk berinteraksi dan melakukan kontrak sosial dengan para peserta pemilu. ${ }^{11}$ Sedangkan demokrasi merupakan suatu diksi yang kerapkali dibicarakan dan terdengar di tengah-tengah kehidupan berbangsa. Dalam berbabagi pembicaraan, kata demokrasi banyak diucapkan dalam berbagai peristiwa dan konteks.

Dalam beberapa literatur, demokrasi dibagi atas dua makna yang digabung. Pertama, dalam makna formil, demokrasi dapat didefinisikan sebagai suatu sistem politik yang memiliki banyak partai yang saling berkompetisi dengan prosedur yang bebas dan jauh dari manipulasi suara, dan memiliki sistem mekanisme pemilihan

\footnotetext{
${ }^{11}$ Muhadam Labolo \& Teguh Ilham, Partai Politik dan Sistem Pemilihan Umum di Indonesia: Teori, Konsep dan Isu Strategis (Depok: Rajawali Pers, 2017), h.51.
}

yang menjamin kebebasan demi terlaksanya hak asasi manusia, yang diorientasikan pada penentuan kepala negara. Sederhanaya, demokrasi dalam makna formil diartikan seebagai proses demokrasi tersebut terus berjalan. Kedua, dalam makna substansialnya, demokrasi menekankan pada keputusan apa yang telah diambil. Artinya, apa yang dilakukan oleh kelompok mayoritas yang telah memenangkan suara rakyat. ${ }^{12}$

Demokrasi dalam tataran historis sebenarnya telah diterapkan sejak zaman Yunani kuno. Konsep demokrasi sangat berelasi dengan konsep negara hukum yang pada waktu itu ditujukan untuk mendobrak penyalahgunaan kekuasaan pemerintah saat itu. Absolusitas pemerintah pada waktu itu berusaha ditumbangkan dengan cara mengganti konsep negara menjadi lebih demokratis. Bahasa sederhananya ialah rakyat menentukan arah pemerintahan yang di dalamnya termuat hak-hak asasi manusia yang harus diutamakan. Untuk mewujudkan itu, maka rakyat membutuhkan aturan-aturan hukum yang secara tegas memberikan pembatasan kepada pemerintah dalam bernegara atau disebut sebagai Konstitusi. Dengan eksisnya negara berlandaskan konstitusi yang didasari pada konsep demokrasi maka akan melahirkan tatanan sistem nilai dan politik yang paling realistik dan

\footnotetext{
${ }^{12}$ Zamroni, Pendidikan Demokrasi Pada Masyarakat Multikultur (Yogyakarta: Ombak, 2013), h. 10-11.
} 
rasional untuk mewujudkan tatanan sosial dalam kehidupan bernegara. ${ }^{13}$

Indonesia sebagai negara yang berprinsip teguh pada konsep demokrasi dalam dinamika kehidupan kenegaraannya menjalankan sistem politik berdasarkan konstitusi negara atau disebut UUD 1945 yang secara tegas menyatakan bahwa Indonesia merupakan negara demokrasi berdasarkan hukum. Hukum dijadikan basis dalam konsep demokrasi untuk mewujudkan tatanan masyarakat yang beradab dan berperikemanusiaan. Dalam Pasal 1 ayat (2) dan (3) dinayatakan bahwa kedaulatan berada di tangan rakyat serta dilaksanakan menurut UUD dan negara Indonesia merupakan negara hukum. Dengan penegasan demikian maka dalam kelembagaan politik, baik pada wilayah suprastruktur maupun infrastruktur harus dijalankan berdasarkan aturan hukum yang demokratis. ${ }^{14}$

Dalam negara demokratis, dikenal istilah partisipasi politik warga negara dalam menentukan pilihannya terkait siapa yang berhak memegang kekuasaan dan pemerintahan dalam suatu negara. Sebab, partisipasi politk merupakan aspek penting dari demokrasi, karena partisipasi politik diartikan sebagai keikut sertaan warga negara biasa dalam menentukan segala keputusan yang menyangkut atau

\section{${ }^{13}$ Bachtiar, Problematika Implementasi} Putusan Mahkamah Konstitusi pada Pengujian UU Terhadap UUD (Jakarta: Raih Asa Sukses, 2015), h. 65 .

${ }^{14}$ Jimly Asshiddiqie, Hukum Tata Negara dan Pilar-pilar Demokrasi (Jakarta: Sinar Grafika, 2015), h. 268. mempengaruhi hidupnya. Dalam ilmu politik, partisipasi diartikan sebagai upaya masyarakat, baik secara individu ataupun kelompok, untuk ikut serta mempengaruhi pembentukan kebijakan publik dalam sebuah negara. ${ }^{15}$

\section{METODE PENELITIAN}

Jenis Peneltian ini ialah penelitian deskriptif kualitatif lapangan. Penelitian ini dilakukan untuk mengumpulkan sejumlah data yang diperoleh dari informan di lapangan untuk menemukan berbagai fakta atau fenomena-fenomena sosial, kemudian menganalisisnya dan berupaya melakukan teorisasi berdasarkan apa yang diamati. ${ }^{16}$ Lokasi Penelitian akan dilakukan di Kota Makassar. Lokasi ini dipilih karena memiliki semua aspek pendukung agar dapat berjalan dengan baik dan Kota Makassar yang kita kenal sebagai daerah sentral politik di Sulawesi Selatan.

Adapun sumber data dalam penelitian ini ialah Ketua Badan Pengawas Pemilu (Bawaslu) Provinsi Sulawesi-Selatan: Laode Arumahi; Ketua Lembaga Swadaya Masyarakat (LSM): Yahya Wildan; Warga Kota Makassar: Afni Nurfita Dewi dan Muharis. Dipilihnya sebagai sumber seperti yang telah disebutkan karena peneliti menganggap bahwa dapat mewakili secara keseluruhan masyarakat

\footnotetext{
${ }^{15}$ Firdaus Muhammad, Komunikasi Politik Islam (Makassar: Alauddin University Press, 2012), h. 185-186.

${ }^{16} \mathrm{M}$. Burhan Bungin, Penelitian Kualitatif (Jakarta: Prenada Media Group, 2007), h. 6.
} 
di Kota Makassar. Data yang telah diolah kemudian dianalisis dengan menggunakan metode analisis kualitatif, dengan pendekatan yuridis normatif. Analisis kualitatif maksudnya adalah analisis data yang dilakukan dengan menjabarkan secara rinci kenyataan atau keadaan atas suatu objek dalam bentuk kalimat guna memberikan gambaran lebih jelas terhadap permasalahan yang diajukan sehingga memudahkan untuk ditarik suatu kesimpulan.

\section{PEMBAHASAN}

\section{Implementasi Undang-Undang Pemilu di} Kota Makassar

Pemilihan Umum merupakan suatu solusi terhadap persoalan demokrasi modern dan juga merupakan upaya memecahkan masalah keterwakilan yaitu bagaimana mewakili berbagai kelompok, kekuatan politik, kepentingan maupun rakyat secara keseluruhan. Saat peneliti menanyakan persoalan bagaimana implementasi Undang-Undang Pemilu dalam meminimalisir pelanggaran-pelanggaran Pemilu di Badan Pengawas Pemilu (Bawaslu) Provinsi Sulawesi-Selatan. Ketua Bawaslu Provinsi Sulsel, Laode Arumahi mengatakan:

"Dalam Undang-Undang Pemilu telah diperintahkan kepada para penyelenggara ,termasuk Bawaslu agar tetap menjaga ritme penyelenggaraan yang akuntabel dan transparan, agar publik percaya bahwa pesta lima tahunan sekali itu benar-benar татри menghadirkan pemimpin dan wakil-wakil rakyat yang dapat dipercaya memegang amanah". ${ }^{17}$

Pernyataan Ketua Bawaslu Sulsel diatas, peneliti menyimpulkan bahwa Bawaslu Provinsi Sulsel turut andil dalam penyelenggaraan Pemilu yang mampu menghadirkan tokoh-tokoh politik kepada masyarakat yang mampu memegang amanah dan tanggung jawab, bukan hanya sekedar perhelatan perebutan kursi kekuasaan di ranah birokrasi pemerintahan ,tetapi sebagai upaya menyejahterakan masyarakat pada umumnya, dan pemilih khususnya. Karena dengan modal itulah, maka masyarakat akan percaya bahwa pihak penyelenggara benar-benar ingin melihat masyarakat sejahtera dalam berbagai lini kehidupan.

Selanjutnya peneliti menanyakan persoalan wacana publik terkait potensi pelanggaran dalam kontestasi Pemilu ialah ada pada pihak penyelenggara itu sendiri, namun Ketua Bawaslu Sulsel, Arumahi membantah hal tersebut dengan mengemukakan:

"Kecurigaan semacam itu dalam pesta demokrasi seperti Pemilu memang seringkali terjadi, namun kami dari Bawaslu Sulsel akan tetap berupaya agar kecurigaan itu hilang di mata masyarakat dengan cara bekerja berdasarkan profesionalitas, karena Undang-Undang

${ }^{17}$ Laode Arumahi, Ketua Badan Pengawas Pemilu (Bawaslu) Provinsi Sulawesi-Selatan di Kantor Bawaslu Sulsel, wawancara 30 Juli 2019. 
Pemilu sendiri telah memerintahkan hal demikian". 18

Pernyataan yang dilontarkan oleh Ketua Bawaslu Sulsel, maka penulis menyimpulkan bahwa penyelenggaran Pemilu yang diharapkan bersih dari praktik-praktik jahat akan mampu diminimalisir berdasarkan perintah dari regulasi yang ada, karena dengan hal semacam itu, maka potensi kecurigaan publik terhadap penyelenggara Pemilu, khususnya Bawaslu akan terminimalisir, sehingga cita - cita menghadirkan pemimpin dan wakil-wakil rakyat yang diharapkan mampu mengahdirkan keadilan dan kesejahteraan dapat dicapai dan dihadirkan di ruang-ruang publik. Insinuasi terhadap pejabat publik, khususnya pihak penyelenggara Pemilu juga lambat laun akan hilang.

Selanjutnya peneliti melakukan wawancara di tingkat elektoral atau pemilih yang berdomisili di Kota Makassar, ternyata ditemukan bahwa implementasi Undang-Undang Pemilu belum berjalan dengan baik, dan masyarakat menilai Badan Pengawas Pemilu (Bawaslu) tidak menerapkan professionalitas kerja mereka, karena di lapangan terutama pada penyelenggaraan Pemilu 17 April 2019 kemarin, masih banyak didapati pelanggaran-pelanggaran Pemilu, salah satunya praktik politik uang atau jual beli suara, hal ini diungkap oleh salah seorang sumber dari sebuah

\footnotetext{
${ }^{18}$ Laode Arumahi, Ketua Badan Pengawas Pemilu (Bawaslu) Provinsi Sulawesi-Selatan di Kantor Bawaslu Sulsel, wawancara 30 Juli 2019.
}

Lembaga Swadaya Masyarakat (LSM) yang bernama Forum Pemuda Nasionalis Indonesia (FPNI), ketika peneliti melakukan wawancara dengan Ketua Umumnya, Yahya Wildan. Informan mengatakan hal yang kurang lebih seperti ini:

"Pada saat penyelenggaraan Pemilu 17 April kemarin, saya sendiri menyaksikan betapa buruknya penyelenggaraan Pemilu tahun ini (2019), karena masih didapati praktik-praktik korup seperti money politic, yang saya duga dilakukan oleh tim sukses salah satu calon peserta Pemilu, bahasa kasarnya ya jual beli suara, dan hal ini justru menjadi kegelisahan kami di FPNI karena praktik seperti itu hanya akan menciptakan wakil-wakil rakyat atau pemimpin yang koruptif jika telah menjabat". ${ }^{19}$

Dari pernyataan Ketua LSM FPNI peneliti menyimpulkan bahwa dalam kondisi di lapangan, masih ada kontradiksi antara regulasi yang berlaku (baca: UndangUndang Pemilu) dan implementasinya di tingkatan masyarakat, karena dari pernyataan informan diatas masih terdapat pelanggaran-pelanggaran Pemilu yang kerapkali terjadi, salah satunya praktik politik uang yang hanya akan menghasilkan tokoh-tokoh politik atau pejabat publik yang koruptif.

Kemudian ketika peneliti menanyakan persoalan kecurigaan masyarakat kepada

\footnotetext{
${ }^{19}$ Yahya Wildan (25), Ketua Umum Forum Pemuda Nasionalis Indonesia (FPNI) di Makassar, wawancara 4 Agustus 2019.
} 
pihak penyelenggara Pemilu, mulai dari Komisi Pemilihan Umum (KPU), Badan Pengawas Pemilu (Bawaslu), Dewan Kehormatan Penyelenggara Pemilu (DKPP) yang diperintahkan oleh UndangUndang Pemilu terkait potensi awal kecurangan Pemilu ada pada pihak penyelenggara, informan peneliti mengataka:

"Kalau menurut saya, memang benar kecurigaan-kecurigaan masyarakat bahwa awal mula terjadinya kecurangan dalam penyelenggaraan Pemilu berada di pihak penyelenggara karena pihak penyelenggara yang menjadi patron atau sumbu penyelenggaraan Pemilu itu sendiri, mereka memiliki otoritas dalam mempolarisasi konsep-konsep yang bermuatan pada kecurangan-kecurangan Pemilu, salah satu contoh menurut penilaian subjektif saya ialah kemarin sebelum masa pencoblosan, KPU yang seharunsnya mampu menetralisir para peserta Pemilu agar mantan narapidana korupsi tidak dapat menjadi daftar calon tetap dalam kontestasi politik, malah KPU membiarkan hal tersebut dengan alibi hak azasi manusia yakni berhak dipilih dan memilih dalam perhelatan Pemilu lima tahunan sekali, inilah yang sebenarnya menjadi preseden buruk bagi demokrasi kita", ${ }^{20}$

Dari pernyataan informan diatas, peneliti berkesimpulan bahwa di tingkat elektoral masih ada yang belum mempercayai pihak

${ }^{20}$ Yahya Wildan (25), Ketua Umum Forum Pemuda Nasionalis Indonesia (FPNI) di Makassar, wawancara 4 Agustus 2019. penyelenggara Pemilu dalam kontestasi politik lima tahun sekali itu, karena kecurigaan-kecurigaan masyarakat kepada pihak penyelanggara masih kerapkali dibicarakan di ruang-ruang publik. Sederhananya ialah abu takkan ada jikalau tak ada api sebelumnya.

Beralih ke informan lain, ketika peneliti bertanya kepada salah satu warga Kota Makassar yang masuk dalam Daftar Pemilih Tetap (DPT) pada kontestasi Pemilu 17 April 2019 kemarin terkait bagaimana implementasi Undang-Undang Pemilu dan apa dampak yang ditimbulkan terhadap pemilih, khususnya di Kota Makassar, informan yang diwawancarai mengatakan:

"Kalau soal penerapan Undang-Undang Pemilu saya rasa telah berjalan baik, karena pastinya pihak penyelenggara juga bersifat profesional dalam menjalankan tugas mereka, meskipun kondisi dilapangan belum sepenuhnya seperti itu karena masih terjadi praktik politik uang sebelum hari pencoblosan". ${ }^{21}$

Dari pernyataan salah satu warga Kota Makassar diatas, maka peneliti berkesimpulan bahwa di tingkat elektoral ternyata masih terjadi praktik politik uang di Kota Makassar terutama saat menjelang hari pencoblosan. Meskipun Bawaslu telah melakukan hal-hal berdasarkan profesional -itas kerja mereka dalam mengawasi

21 Muharis (23), Warga Kota Makassar di Warkop Daeng, Kecamatan Rappocini, Kota Makassar, wawancara 9 November 2019. 
proses Pemilu agar menghindari pelanggaran-pelanggaran Pemilu.

Pertanyaan mengenai kecurigaan masyarakat terhadap pihak penyelenggara Pemilu yang berpotensi melakukan kecurangan dalam penyelenggaraan pesta lima tahunan sekali itu, informan mengatakan:

"Hal itu kan masing-masing pendapat orang, kalau saya pribadi ya tidak curiga dengan para pihak penyelenggara karena pastinya mereka akan bekerja secara professional karena telah dipercayakan oleh masyarakat dan diberikan kewenangan oleh Undang-Undang yang berlaku. Menurut penilain orang lah kalau terkait hal itu". ${ }^{22}$

Peneliti berkesimpulan bahwa masih ada masyarakat terutama warga Kota Makassar yang masih ragu dengan kredibilitas penyelenggara Pemilu yang mengklaim bekerja secara professional untuk menghadirkan para pemimpin atau wakil-wakil rakyat yang dapat memegang amanah jika terpilih sebagai Kepala Negara, Kepala Daerah atau wakil rakyat di Parlemen.

\section{Peran Bawaslu Sulsel dalam Meminimalisir Pelanggaran Pemilu}

Badan Pengawas Pemilu (Bawaslu) sebagai lembaga pengawal terpercaya dalam penyelenggaraan Pemilu demokratis, bermartabat dan berkualitas

${ }^{22}$ Afni Nurfita Dewi (22), Warga Kota Makassar di Kampus 2 UIN Alauddin Makassar, Samata Kabupaten Gowa, wawancara 5 Agustus 2019. sebagaimana visinya, maka diharapkan mampu berperan dalam peminimalisiran terjadinya pelanggaran Pemilu yang dari dulu telah menggerogoti semarak perayaan pesta demokrasi lima tahunan sekali itu.

Berikut hasil wawancara peneliti dengan para informan sebagai berikut. Pihak Badan Pengawas Pemilu (Bawaslu) Provinsi Sulawesi-Selatan, ketika peneliti menanyakan tentang apakah Bawaslu Sulsel telah bekerja secara professional dalam meminimalisir pelanggaran Pemilu yang ada di Kota Makassar.

"Kami dari Bawaslu Sulawesi-Selatan pastinya telah berupaya untuk menerapkan perintah dari UndangUndang Pemilu yang menginginkan agar Pemilu berjalan secara professional dan mampu dipercayai oleh masyarakat terkait hasil yang akan diumumkan oleh KPU mengenai peserta Pemilu yang menang dalam kontestasi politik itu. Bukti nyata terkait hal tersebut ialah menerima beberapa laporan dari masyarakat terkait adanya dugaan pelanggaran Pemilu yang terjadi di tingkat elektoral, karena kami punya datanya. Kami menghimpun data dari beberapa Kabupaten terkait dugaan pelanggaran Pemilu yang terjadi, baik yang masuk dalam kategori pidana Pemilu ataupun pelanggaran administratif yang dilakukan oleh peserta pemilu itu sendiri", 23

23 Laode Arumahi, Ketua Badan Pengawas Pemilu (Bawaslu) Provinsi Sulawesi-Selatan di Kantor Bawaslu Sulsel, wawancara 30 Juli 2019. 
Dari pernyataan Ketua Bawaslu Sulsel, Laode Arumahi diatas maka peneliti menyimpulkan bahwa pihak dari Bawaslu sebagai lembaga yang memiliki wewenang dalam mengawasi terjadinya pelanggaran Pemilu di tingkat elektoral telah diterapkan, dengan menerima dan mengindahkan laporan yang masuk di Bawaslu Sulsel yang diadukan oleh masyarakat yang merasa dirugikan oleh oknum yang melakukan pelanggaran Pemilu.

Berikut ini data laporan yang masuk ke Bawaslu Sulsel, terkait validasi data dugaan pelanggaran dan hasil penanangan pelanggaran Pemilu di Kota Makassar yang peneliti terima ketika melakukan penelitian.

Kota Makassar:

- Dugaan Pelanggaran Diterima: Administrasi: 11; Kode etik: 1; Pidana: 30; Hukum lainnya: 17.

- Hasil Penanganan: Administrasi: 10; Kode Etik: 2; Pidana: 1; Hukum lainnya: 17; Proses: 1; Bukan pelanggaran: 28 .

- Total: 59.

Dari data yang penelitian tersebut, maka disimpulkan bahwa Bawaslu Provinsi Sulawesi-Selatan telah menjalankan professionalitas kerja mereka karena telah melakukan riset terkait mana saja yang masuk dalam kategori pidana pemilu, pelanggaran administratif maupun hukum lainnya dari hasil laporan yang masuk di Bawaslu Sulsel, khususnya pelanggaranpelanggaran Pemilu di Kota Makassar.
Disimpulkan bahwa lebih banyak laporan yang masuk terkait pidana Pemilu yang terjadi di lapangan, meskipun yang ditangani oleh Bawaslu yang diperkuat dengan alat bukti ialah hanya 1 yang lolos untuk ditindak lebih lanjut oleh Komisi Pemilihan Umum terkait hukuman yang akan diberikan kepada pelanggar. Karena tugas Bawaslu sendiri ialah hanya memproses laporan yang diadukan oleh masyarakat terkait pelanggaran Pemilu. Dan jika telah masuk ke dalam kategori pidana Pemilu, maka Bawaslu akan bekerjasama dengan Gakkumdu yang dalam strukturisasinya ditangani oleh aparat Kepolisian dan Kejaksaan.

Peneliti melanjutkan pertanyaan berikutnya mengenai langkah apa yang telah dilakukan oleh Bawaslu Sulsel dalam meminimalisir pelanggaran Pemilu yang ada di Kota Makassar. Jawaban dari pihak Bawaslu Sulsel sebagai berikut:

"Langkah yang kami lakukan ialah dengan mengintruksikan kepada Bawaslu Kota Makassar agar melakukan edukasi kepada masyarakat agar tak melakukan kecurangan-kecurangan Pemilu, karena hal itu juga akan berdampak pada mereka. Karena jika awalnya sudah curang maka hasilnya juga akan tidak baik. Dengan edukasi semacam itu, kami yakin potensi melakukan kecurangan yang sifatnya melanggar atau keluar dari norma-norma yang berlaku akan minim terjadi", ${ }^{24}$

${ }^{24}$ Laode Arumahi, Ketua Badan Pengawas Pemilu (Bawaslu) Provinsi Sulawesi-Selatan di Kantor Bawaslu Sulsel, wawancara 30 Juli 2019. 
Pernyataan dari pihak Bawaslu Provinsi Sulsel terkait upaya yang telah dilakukan oleh Bawaslu Sulsel dalam melakukan pencegahan agar tak terjadi pelanggaran Pemilu ialah hal yang sifatnya preventif. Dalam kajian ilmu hukum juga hal tersebut juga banyak dibicarakan oleh para ahli-ahli hukum, sederhananya ialah pencegahan dini lebih baik dibanding menindaklanjuti jika kecurangan telah terjadi.

Selanjutnya peneliti melakukan wawancara dengan informan lain yaitu pihak dari Lembaga Swadaya Masyarakat (LSM) di Kota Makassar. Dengan pertanyaan yang sama yaitu peran Bawaslu dalam meminimalisir pelanggaran Pemilu di tingkat elektoral. Adapun hasil wawancara dari pihak LSM:

"Saya rasa kalau persoalan peran instansi negara yang tugas, wewenangnya menyelenggarakan Pemilu seperti Bawaslu telah jelas diatur dalam UndangUndang Pemilu. Dan jika misalnya ada tugas, fungsi dan wewenang yang keluar dari aturan tersebut, maka sana saja Bawaslu juga melakukan pelanggaran terkait aturan yang ada, mau jadi seperti apa Pemilu yang kita selenggarakan? Makanya kami dari LSM sangat berharap Bawaslu professional dalam menindaklanjuti laporan-laporan yang masuk, artinya tidak tebang pilih untuk memproses hukum pengaduan dari masyarakat agar tingkat kepercayaan publik terhadap pihak penyelenggara Pemilu itu makin tinggi dan tak ada lagi kecurigaan di kalangan publik, terutama pemilih". 25

Pernyataan dari pihak dari LSM di Kota Makassar diatas ialah gambaran masih adanya kepercayaan masyarakat kepada Bawaslu yang diberikan amanah untuk mengawasi jalannya penyelenggaraan Pemilu yang Jujur dan Adil sebagaimana azas Pemilu yang berlaku. Meskipun masih ada rasa pesimis oleh pihak LSM terkait professionalitas Bawaslu dalam memproses pengaduan dari masyarakat, agar Bawaslu tidak tebang pilih dalam menindaklanjuti pengaduan-pengaduan itu.

Sementara respon positif terkait professionalitas kerja Bawaslu Sulsel dikatakan oleh informan ketiga peneliti yang mengemukakan hal sebagai berikut:

"Menurut saya peran Bawaslu sebagai pihak pengawas jalannya Pemilu kemarin ialah sangat bagus dengan alasan adanya anggota dari Bawaslu yang melakukan audit di Tempat Pemungutan Suara (TPS). Karena saya dan Ibu saya berbeda TPS untuk memilih. Ibu saya juga mendapati ada anggota Bawaslu yang terlibat dalam proses pengawasan selama di TPS, mungkin tujuannya untuk menindaktegas oknum yang tertangkap tangan melakukan kecurangan". 26

\footnotetext{
${ }^{25}$ Yahya Wildan (25), Ketua Umum Forum
} Pemuda Nasionalis Indonesia (FPNI) di Makassar, wawancara 4 Agustus 2019.

26 Afni Nurfita Dewi (22), Warga Kota Makassar di Kampus 2 UIN Alauddin Makassar, Samata Kabupaten Gowa, wawancara 5 Agustus 2019. 
Pernyataan informan ketiga, peneliti berkesimpulan bahwa yang dimaksud pihak pengawas di Tempat Pemungutan Suara (TPS) ialah Panitia Pengawas Pemilu (Panwaslu) yang berada dibawah Bawaslu. Dari pernyataan informan diatas, peneliti berkesimpulan bahwa telah ada upaya dari Bawaslu dalam meminimalisir terjadinya pelanggaran Pemilu di tingkat elektoral dengan cara menyiapkan tiap anggota Panwaslu di tiap TPS yang berada di Kota Makassar.

\section{PENUTUP}

Berdasarkan pembahasan dan penelitian yang dilakukan, maka peneliti menarik dua kesimpulan. Pertama, bahwa pelaksanaan Undang-Undang Nomor 7 Tahun 2017 tentang Pemilihan Umum dalam memnimalsir pelanggaran pemilu terutama di tingkat elektoral ialah instansi negara yang diberikan kewenangan dalam menjalankan tugasnya sebagai pengawas Pemilu yakni Badan Pengawas Pemilu (Bawaslu) belum bekerja secara professional karena professionalitas kerja Bawaslu Sulawesi-Selatan masih diragukan oleh masyarakat khususnya pemilih dan LSM, karena masih didapati beberapa jenis pelanggaran Pemilu ketika pesta demokrasi lima tahunan sekali itu diselenggarakan. Kedua, Bawaslu Sulsel telah melakukan langkah pencegahan dan juga cepat tanggap dalam menerima aduan dari masyarakat jika terjadi pelanggaran Pemilu yang dilarang dalam UndangUndang Pemilu. Bawaslu SulawesiSelatan juga telah memerintahkan anggota Panitia Pengawas Pemilu (Panwaslu) agar mengaudit secara langsung Tempat Pemungutan Suara (TPS) yang ada di Kota Makassar untuk meminimalisir terjadinya pelanggaran Pemilu di hari pencoblosan.

$* * *$

\section{DAFTAR PUSTAKA}

A. Bakir Ihsan, Etika dan Logika Berpolitik (Bandung: Remaja Rosdakarya, 2009).

Agus Pramono, Elite Politik: Yang Loyo dan Harapan Masa Depan (Jakarta: Pustaka Sinar Harapan, 2005).

Bachtiar, Problematika Implementasi Putusan Mahkamah Konstitusi pada Pengujian UU Terhadap UUD (Jakarta: Raih Asa Sukses, 2015).

Firdaus Muhammad, Komunikasi Politik Islam (Makassar: Alauddin University Press, 2012).

Hafied Cangara, Komunikasi Politik: Konsep, Teori, dan Strategi (Jakarta: Rajawali Pers: 2009).

Jimly Asshiddiqie, Hukum Tata Negara dan Pilar-pilar Demokrasi (Jakarta: Sinar Grafika, 2015)

M. Burhan Bungin, Penelitian Kualitatif (Jakarta: Prenada Media Group, 2007).

Moh. Mahfud MD, "Kata Pengantar", dalam Ni'matul Huda \& M. Imam Nasef, Penataan Demokrasi dan Pemilu di Indonesia Pasca 
Reformasi (Jakarta: Kencana, 2017).

Muhadam Labolo \& Teguh Ilham, Partai Politik dan Sistem Pemilihan Umum di Indonesia: Teori, Konsep dan Isu Strategis (Depok: Rajawali Pers, 2017).

Ni'matul Huda \& M. Imam Nasef, Penataan Demokrasi dan Pemilu di Indonesia Pasca Reformasi (Jakarta: Kencana, 2017).

Rozali Abdullah, Mewujudkan Pemilu yang Lebih Berkualitas (Pemilu Legislatif) (Jakarta: Rajawali Pers, 2009).

Zamroni, Pendidikan Demokrasi Pada Masyarakat Multikultur (Yogyakarta: Ombak, 2013).

\section{Wawancara}

Afni Nurfita Dewi (22), Warga Kota Makassar di Kampus 2 UIN Alauddin Makassar, Samata Kabupaten Gowa, wawancara 5 Agustus 2019.

Laode Arumahi, Ketua Badan Pengawas Pemilu (Bawaslu) Provinsi Sulawesi-Selatan di Kantor Bawaslu Sulsel, wawancara 30 Juli 2019.

Muharis (23), Warga Kota Makassar di Warkop Daeng, Kecamatan Rappocini, Kota Makassar, wawancara 9 November 2019.

Yahya Wildan (25), Ketua Umum Forum Pemuda Nasionalis Indonesia
(FPNI) di Makassar, wawancara 4 Agustus 2019.

\section{Website}

Himawan, "Bawaslu Banyak Temukan Dugaan Politik Uang Pada Pelanggaran Pemilu di Makassar" dalam https://regional.kompas.com /read/2019/04/13/13044661/bawasl u-banyak-temukan-dugaan-politikuang-pada-pelanggaran-pemilu-di, diakses pada 5 Mei 2019.

Mela Arnani, "Bawaslu Temukan 548 Pelanggaran Pidana Pemilu, Ini Paparannya"dalam https://nasional. kompas.com/read/2019/04/09/1819 0341/bawaslu-temukan-548-pelang garan-pidana-pemilu-inipaparannya, diakses pada 5 Mei 2019. 